\title{
Ideological and Political Education from the Perspective of Persuasion Theory
}

\author{
Li Zhu \\ Academy of Marxism, \\ Wuhan Polytechnic University, \\ Wuhan, 430023, China
}

\begin{abstract}
Ideological and political education and persuasion theory have an inherent fit. From the perspective of persuasion theory, it analyzes the problems existing in ideological and political education workers, educational content and educational methods, draws on the relevant content of persuasion theory, and proposes corresponding countermeasures, which will undoubtedly improve the effectiveness of ideological and political education.
\end{abstract}

Keywords-persuasion theory; ideological and political Education; problem; countermeasures

\section{INTRODUCTION}

College ideological and political theory courses are the main channel for ideological and political education for college students, and an important way to help college students establish a correct world outlook, outlook on life and values. General Secretary Xi Jinping pointed out: "The ideological and political theory class is the key course for the implementation of the fundamental tasks of Lide Shuren. The adolescent stage is the life-threatening stage of life, which needs to be carefully guided and cultivated." Contemporary college students have instinctive appeals to national politics, moral feelings, right and wrong judgments, but to some extent, they also have a psychological weakness, exquisite self-interest and other ills, and are vulnerable to so-called "universal values", "historical nihilism" and "neo-liberalism". The influence of bad thoughts is easy to breed negative or even contradictory attitudes in ideological and political theory courses. It is easy to breed negative or even contradictory attitudes toward ideological and political theory courses. Mainly in the ideological and political theory class is not interested, the ideological and political theory class teachers are not high, and the importance of ideological and political theory courses is insufficient. Therefore, improving the effectiveness of ideological and political education in colleges and universities has become an important issue to be solved urgently.

Ideological and political education is "social or social groups use certain ideas, political opinions and ethics, exerting purposeful, planned and organized influence on their members, so that they can form social practice that meets the ideological and moral requirements required by certain society activity." [1]Ideological and political education is the process by which

This article is the phased results of the 2017 Humanities and Social Sciences Project of Hubei Provincial Department of Education: Empathy and Youth Moral Development (17Y068) and the phased results of Wuhan Polytechnic University School-level Teaching Research Project: 2018 Edition "Basic Course" Teaching Reform Stage Results Based on Attitude Persuasion Model (XM201801). educators exert ideological and political education on educators and the influence of educators on ideological and political education. From the perspective of social psychology, ideological and political education in colleges and universities is the ideological and political theory of the ideological and political educators (teachers), using appropriate methods and methods to gradually guide the educational objects (college students) to establish a correct and positive attitude and change the negative backwardness. Attitude, making it accept the process of socialization of social rules. Therefore, using the attitude change persuasion theory to examine and guide the ideological and political education process will undoubtedly improve the effectiveness and pertinence of ideological and political education in colleges and universities.

\section{Attitude Changes the InNER Fit OF PERSUAsion THEORY AND IDEOLOGICAL AND POLITICAL EDUCATION}

In 1959, the American psychologist Hoffland proposed the famous "Yale Persuasion Model". Its constituent elements mainly include persuaders, persuaders, and persuasion information and persuasion situations. Among these four elements, the persuader, persuasion, and persuasion are external stimuli that change the attitude of the persuader. Persuasion theory and ideological and political education have an inherent fit. First of all, there is a one-to-one correspondence between the two elements. Ideological and political education also has four components, namely, ideological and political educators, ideological and political education objects, ideological and political education content, and ideological and political education environment. The persuaders in persuasion theory correspond to ideological and political educators, the persuaded person corresponds to the educated person, Persuasion information corresponds to the content of ideological and political education, the persuasion situation corresponds to the moral education environment. American sociologist Thomas believes that the actor's perception and perception of the environment before the action is not purely objective, but subjectively grasped and stipulated. Therefore, the ideological and political education environment is obviously also the ideological and political education situation in which subjective and objective are unified, which is also intrinsically consistent with the persuasive situation of the persuasion model.

Secondly, the inner conformity of persuasion theory and ideological and political education in colleges and universities has a clear goal in both, and it is to change the object toward 
the established goal by implementing certain influences. The purpose of ideological and political education in colleges and universities is to transform certain ideological concepts, political views and moral norms into the inner consciousness and attitude of college students, and to externalize them into real-life actions, that is, internalization in the heart and externalization in the line. The persuasion theory is that the persuader changes the attitude of the persuader by exerting a certain influence on the persuaded person.

Once again, the inner conformity of persuasion theory and ideological and political education in colleges and universities is manifested in the fact that both of them reflect the will of the implementers. The ideological and political education in colleges and universities reflects the will of certain social or social groups, and its ideological and political orientation is its essential feature. Compared with ideological and political education in colleges and universities, the persuasive content of persuasion theory is more diversified. From personal preferences, consumption patterns, behavior habits and values, it may be composed of persuasion content, but they all reflect the will of the persuader. Therefore, " Drawing on the theory of attitude change and studying ideological and political education activities has important theoretical and practical value for improving the scientific, effective and pertinent of ideological and political education and realizing the established goals of ideological and political education."[2]

\section{Problems In The Process OF IdeOlOGICAL AND}

Political EducAtion IN THE Perspective of PERSUASION THEORY

\section{A. Problems in the ideological and political education under the persuasion theory}

Ideological and political educators are the communicators and persuaders of the influence of ideological and political education, and play a dominant role in the process of ideological and political education. Persuasion theory believes that there are two main factors that influence the persuasive influence on attitude change, one is the persuasive' credibility, and the other is the persuasive' attractiveness. The credibility of the persuader depends on whether the persuader has authority and whether the persuader is trustworthy. The higher the authority of the persuader, the greater the likelihood that the persuaded person will change his attitude. In the current ideological and political education in colleges and universities, the authority of educators mainly comes from the qualifications and experience in the traditional sense. With the development of information technology and the iterative updating of electronic products, the ability and speed of college students to acquire new knowledge far exceeds that of educators, and the authority of educators in the traditional sense is instantly resolved. This will undoubtedly have a negative impact on the attitude of the education target.

The persuasion theory holds that the persuasive attractiveness is also an important factor affecting the attitude of the persuasive object. People have a higher degree of recognition for highly attractive persuaders and are more likely to accept persuasive information and change attitudes. Emotional transfer theory also believes that people's positive attitude toward something will shift to another thing that is related to the thing, which is what we usually call "love house and black." Kelman believes that "because people try to equate to a favorite communicator, and often take that person's attitudes, hobbies, behaviors and styles of clothing, so like to cause attitude changes." An important factor in determining the attractiveness of the persuader comes from the similarity between the persuasive and the persuasive. In the ideological and political education of colleges and universities, the similarity between educators and educates comes from the degree of understanding of college students by ideological and political teachers. At present, in the ideological and political education of colleges and universities, the elective course system and the separation of teaching in one class and multiple classes, the interaction between most ideological and political theory teachers and students is limited to the classroom, and there are few contacts and contacts after class. The possibility of attraction is very small.

\section{B. Problems in the content of ideological and political education under the perspective of persuasion theory}

Persuasion theory believes that in communication persuasion, the repeated presentation of opinions will lead to an increase in the number of consents, but when the views are repeated to a certain limit, the number of consents will decline. "Whether the ideas presented are what the participants want to hear (they are very different from their current positions), or what they don't want to hear (very different), the results are inverted U-shaped curves."[3]In the current ideological and political education of colleges and universities, the repetitiveness of content is obvious. Firstly, it is reflected in the repetition of the content of college ideological and political theory courses and middle schools moral education courses, such as the repetition of the content of ideological and moral cultivation and legal basis and the content of middle school moral education curriculum. Secondly, it is expressed in the repetitiveness of the content between the various courses of the university ideological and political theory course. For example, the content of the "Outline of Modern and Contemporary Chinese History" and the "Theory System of Socialism with Chinese Characteristics" is repetitive. It is undeniable that the repetitiveness of the content of the curriculum will enhance the coherence and subtleness of the effect of ideological and political education, but it is very likely to cause college students to over-reverse the repetitive psychology of ideological and political education. Biological and psychological studies have shown that living organisms have limited acceptance of any stimulus provided by the outside world. When the amount of stimulation exceeds a certain level, the body's response will change from satisfaction to injury to escape this stimulus.

\section{Problems in the ideological and political education mode under the perspective of persuasion theory}

The control of information is called the information framework in modern persuasion theory, the information framework is different, and the persuasion effect is different. Persuasion theory believes that persuasive often use unilateral presentation and two aspects to present two information frameworks. The use of unilateral or two-sided information 
presentation depends on the degree of education of the persuasive object. For persuasive subjects with lower education level, unilateral information is often presented, while for persuasive subjects with higher education level, it is necessary to provide positive and negative information. "Unilateral information is not sufficiently persuasive. To make the object truly convinced, it must present double-sided information."[4]

In the current ideological and political education in colleges and universities, pathological persuasion has become a normal state. The so-called pathological persuasion means that "the persuader is not completely accurate in presenting all kinds of important relevant information to the persuaded party, and only by some means to induce the other party, so that the other party changes in cognition." [5] The pathological persuasion in the ideological and political education of colleges and universities is mainly manifested in the fact that teachers of ideological and political schools often adopt concealment or anti-blocking attitudes to certain non-mainstream ideas, focusing on instilling mainstream values into college students. Contemporary college students already have a certain amount of knowledge accumulation, and initially formed their own value system and ability to judge things. This pathological persuasion method has not been able to convince college students.

\section{THE IMPROVEMENT COUNTERMEASURES OF IDEOLOGICAL AND POLITICAL EDUCATION IN COLLEGES AND UNIVERSITIES UNDER THE PERSPECTIVE OF PERSUASION THEORY}

A. Improvement Countermeasures of College Ideological and Political Educators from the Perspective of Persuasion Theory

In order to improve the effectiveness of ideological and political education, and to draw on the authoritative effect of persuasive on persuasive attitudes in persuasion theory, college ideological and political educators can be promoted from two aspects: authority and attraction. "Ideological and political to achieve results, one must rely on the power of truth, the second depends on the power of personality." [6] Ideological and political education is a cross-disciplinary applied discipline involving psychology, education, sociology, political science, and management. Firstly, aiming at the problem of the elimination of the traditional authority of ideological and political educators, ideological and political educators in colleges and universities need to rebuild their authority by upgrading their knowledge, qualifications and experience. In addition to strengthening his own Marxist theoretical literacy and mastering the professional knowledge of ideological and political education, he also needs to extensively explore the knowledge of related disciplines, so as to continuously optimize his knowledge structure. In the era of rapid technological development, college ideological and political educators must learn to use new technologies to enhance educational effects, such as using flip classrooms, live webcasts, 5G technology and VR technology to add a steady stream of energy to ideological and political education.

Secondly, ideological and political educators also need to enhance their personality charm. The persuasion theory believes that the persuader can establish the common point and similarities with the persuasive objects to narrow the psychological distance between the two, and create a "self-human effect" to change the attitude of the persuasive object. On the one hand, ideological and political educators need to pay attention to the hobbies, knowledge structure, psychological characteristics, etc. of the educational objects, learn to create opportunities in and out of the classroom, let go of the equal and friendly exchanges with the students, and actively listen, understand and appreciate the educational objects. On the other hand, ideological and political educators need innovative ways of expressing discourse. For example, they can use the online language or game discourse that students like to hear to communicate, understand the social hotspots and social phenomena that students care about, and analyze their crux with an equal and democratic attitude. Clear up the ideas so that they can "know their teachers and believe in their own way."

\section{B. Improvement Countermeasures of the Contents of Ideological and Political Education in Colleges and Universities from the Perspective of Persuasion Theory}

According to persuasion theory, the content of ideological and political education in colleges and universities and the repetitiveness of moral education content in middle school, as well as the content cross between colleges and universities in ideological and political education may cause college students to over-reverse the repetitive psychology of ideological and political education. This requires us to grasp the dialectical unity between the repetition of educational content and development and change. On the one hand, the purpose of ideological and political education in colleges and universities is to enable students to firmly believe in communism and faith in socialism, and to appropriately repeat relevant content to increase familiarity can help college students accept the belief. On the other hand, it should be noted that the repeatability of content is not the same as the simple mechanical repetition of the same content. Because the times are constantly evolving and changing, the educational objects are constantly evolving and changing. This requires continuous enrichment of educational content in light of reality. It is necessary to aim at the actual needs of college students in the new era of today, and to achieve the right medicine and targeted. Therefore, the content of ideological and political education in colleges and universities needs to teach college students to correctly understand the world, and transform their own understanding into realistic actions, so that college students can better understand the world, understand China and grasp the times.

\section{Improvement Countermeasures of Ideological and}

Political Education in Colleges and Universities from the Perspective of Persuasion Theory

The pathological persuasion and one-way instillation in ideological and political education cannot convince college students, and the effect of ideological and political education is naturally minimal. According to the vaccination theory in the persuasion theory, the persuaded person first accepts the appropriate amount and mild negative information, and then inspires and guides the analysis and criticism of the negative information, allowing the persuasive object to recognize the error and generate the immune effect. This vaccination theory is similar to the "breeding vaccination method" proposed by 
Comrade Mao Zedong in the past. He said: "Why do you want to breed vaccinia? It is to artificially put a virus into the human body and carry out 'bacterial warfare' to fight against you and make your body immune." [7]In ideological and political education, we adopt a fair and objective attitude towards non-mainstream values, and through questions, hypotheses, and inspirations to analyze students, find their mistakes and absurdities, and thus consciously exert immunity to them.

\section{CONCLUSION}

Using the theory of persuasion to analyze the problems existing in the current ideological and political education of educators, educational content and educational methods, in order to improve the effectiveness of ideological and political education in colleges and universities, it can be improved from the following three aspects: educators need to improve their authority and attractiveness; the choice of educational content needs to grasp the dialectical unity between repetitiveness and developmental change; the educational method needs to avoid pathological persuasion and one-way infusion, and adopt an objective and fair attitude towards non-mainstream values to present the positive and negative aspects, thus changing the attitude of the educational objects.

\section{REFERENCES}

[1] Department of Social Science Research and Ideological and Political Education of the Ministry of Education The principle of ideological and political education. Beijing: Higher Education Press, 1999.

[2] L.M Wu, Research on the Application of Attitude Change Theory in College Ideological and Political Education. Guide to Ideological and Theoretical Education, 2010, (9): 95-97.

[3] S.E Taylor, et al., Social psychology. Beijing: Peking University Press, 2004.

[4] G.C Chu, Prior familiarity, perceived bias, and one-sided versus two-sided communications. Journal of Experimental Social Psychology, 1967, 3(3):243-254

[5] H.J Chen, A New Probe into the Rebellious Psychology in College Students' Ideological and Political Education. Ideological and theoretical education guide, 2006 (9):69-72.

[6] Y.C Zhang, A.X Lu, On the Education Charm of Educators. Ideological and Political Education of University of China, 2005(9):30-32.

[7] Mao Zedong's Anthology, Volume 7. Beijing: People's Publishing House, 1999. 